\title{
The Access to Information in MERCOSUR for Sustainable Development
}

\author{
By Gabriela Soldano Garcez*
}

Since environmental quality is considered to be a feature indispensable to a healthy and dignified life, civil society must integrate the decision-making processes involving inalienable rights such as the protection of the environment. In this context, pursuant to article 225 of the Federal Constitution of Brazil of 1988, the defense and protection of the ecologically balanced environment for present and future generations is a responsibility of both the Government and the community.. However, proper information being inaccessible there is not a basis for making a well-educated decision, thus rendering society unable to participate in this process. In this sense, access to environmental information constitutes not only an implementation tool but also a significant prerequisite for public participation in environmental matters, since information is a major source of knowledge. At the first stage of this study, the various concepts of environmental information as well as their societal importance are discussed. Then, the study ponders upon the legislation that guarantees access to environmental information in the MERCOSUR member countries: Uruguay, Paraguay, Argentina and Brazil. The needs for integration of public policies for environmental protection by this Latin American community, as well as for the establishment of thematic environmental education, directly related to the process of sustainable development, were among the priorities of the Treaty of Asuncion, establishing the MERCOSUR in 1991. In this context, the right of access to information in the MERCOSUR countries appears to be of outmost importance. Finally, the paper concludes that information, being the cornerstone of ethics and good citizenship, is regarded as a basic instrument for building environmental awareness of the population as well as essential for sustainable development, being the ultimate target set by Agenda 21. Public policies for environmental education and awareness can only be effectively implemented on the basis of integration between the neighboring, Latin American countries, being part of a block which seeks economic integration, as well as political, social and cultural development.

Keywords: Environment; Information; Education; Awareness; Sustainable Development; MERCOSUR.

\section{Introduction}

The article 225 of the Brazilian Constitution of 1988 sets out the fundamental right to a balanced environment, treating environmental quality as an indispensable element to a healthy and decent life.

The importance of the environment is indisputable not only for the current generations, but also for the ones yet to come.

${ }^{*}$ Master in Environmental Law and PhD student in International Environmental Law, Catholic University of Santos - UNISANTOS, Brazil. 
In this context, the commitment and responsibility of the citizens in being actively involved in the defense and protection of the environment should be highlighted.

It is argued in the present paper that in order to ensure citizens' participation, it is necessary for the population to have access to information of high quality.

The access to environmental information is an important precondition for public participation in environmental matters. Public access to environmentrelated informational sources as well as the provision of environmental education is considered to significantly contribute to the process of raising society's consciousness and serve the purpose of building a sustainable development, as stated in Agenda 21.

In these terms, the present article aims to analyze the sources and types of environmental information as well as public access to them in the countries composing the group referred to as MERCOSUL: Uruguay, Paraguay, Argentina and Brazil.

Finally, the importance of public information as an instrument for incentivizing environment- friendly behaviour, raising consciousness and enhancing sustainable development is identified.

\section{A Global View of Environmental Information}

Information, being transformed into knowledge to analyse facts, constitutes the basis for any decision-making regarding inalienable rights such as the right to a healthy environment.

The Aarhus Convention, prepared during the $4^{\text {th }}$ Ministerial Conference of Environment for Europe in 1988 guarantees the right to access to information, public participation in the process of decision-making and equality of justice access. According to the second Article "environmental information" is defined as:

Any written, visual, oral, electronic information available, or in any other way about:

a) state of the elements of environment such as air and atmosphere, water, soil, land, landscape, natural sites, biological diversity and its components, including, generically, modified organisms and the interaction among these elements;

b) Factors, such as substances, energy, noise and radiation, activities or measures, including administrative measures, deals, policies, legislation, plans and programs concerning the environment which affect or might affect the elements of the environment, within what was mentioned above subparagraph a), and cost-benefit and other presuppositions and economical analysis used in the process of decision-making concerning the environment; 
c) State of human health and public safety, conditions of human life, cultural sites and engineered structures, as far as they can or might be affected by the state of the elements of environment or, through those elements, by the factors, activities or measures mentioned above in subparagraph $b$ ).

Even though access to the full range of technical data should be granted to the interested parties, environmental information should primarily be comprehensible by non-experts as it is meant to serve the needs of the general public for keeping up to date with the developments of the environmental issues.

"Clarity should coexist with accuracy, not permitting incompleteness of information under the pretext of being didactic" (MACHADO, 2006: 96).

Access to environmental information should be granted in a quick and effective manner, since delays in information transmission can cause permanent environmental damage.

The information ought to be capable of giving the dimension of the danger perceived by the informant organ, as well as give valid suggestions, capable to lead advised ones to a safe behavior (MACHADO, 2006: 92).

\section{The Access to Information in the MERCOSUR Countries}

In 1991, with the Asunción Treaty signed, an international market among Brazil, Paraguay, Argentina and Uruguay (MERCOSUL) was established and jointly regulated, in the attempt of these countries to achieve economical, political, social and cultural integration of the Latin-America people. According to article $4^{\circ}$ of the Brazilian Constitution, the notion that these nations shared, also serving as the main incentive underlying the creation of the union, was "the formation of a Latin-American community of nations".

The right to free access to informational sources in the MERCOSUL countries is extremely important as it constitutes a particularly relevant stage in the process of public policies integration for the benefit of the environmental surroundings of this Latin-American community. Easily- accessible, highquality information is considered to be a prerequisite for sustainable development, an agreement prioritized in the preamble of the Asunción Treaty:

Considering that the expansion of the current dimensions of the national markets, through integration, constitutes a fundamental condition to speed their processes of economic development with social justice;

Understanding that this objective should be reached by the more effective exploitation of resources available and the preservation of environment (...). 
MERCOSUL's agreement about Environment (Promulgated in Brazil by Decree 5.208/2004 in 2001), aiming to promote the "effective participation of the civil society concerning the handling of environmental matters" (article $3^{\text {rd }}$ ), adopts as one of its main thematic areas the environmental education, information and communication. Article 6 also sets up the increment of "exchange of information about environmental laws, regulations, procedures, policies and practices which can affect either the commerce or the conditions of competition within the Mercosur" as the fundamental purpose of this cooperation.

In the following sections, an analysis of the access to environmental information guaranteed on a legal basis is conducted across MERCOSUR countries.

\section{Uruguay}

In 1996, Uruguay elevated the concept of environment to the constitutional level (article 47), laying the responsibility its protection and preservation on both the public power and to the community.

Regarding the information access, Uruguay enacted the Law on access to Public Information (Law 18.381/08), regulated in 2010, explicitly stating that the access to information is everyone's right, including both physical and legal persons and also applying to all the public bodies. Such organisms are referred to as "subjects obliged by the scope of application" within the context of the legislation.

According to the Law 18.381/08, all the information produced is considered to be public independently both of the legal subject that owns it and the context within which it was obtained (article $4^{\circ}$ ). Moreover, the subjects who own information are responsible of the proper organization, systemization and availability of the information, ensuring wide and easy access to all parties concerned (article $5^{\circ}$ ).

Additionally, the regulatory Decree of 2010, predicts the following (article 17): "Every file, register or data contained in any media, document or printed, optical, electronic, magnetic, chemical, physical or biological register found held by the obliged subjects".

The same Decree states that the public information network has to be updated and available without previous request (article 18).

Every person interested can request access to the informational network directly from the qualified organism. In case the access is denied, the applicant can instigate a Legal Action to Access Public Information (Article 23, Law 18.381/08).

Thus, in order for the information to be considered reserved and, therefore, confidential, there should be a reasonable decision on the basis of objective elements, demonstrating the need for secrecy on account of potential "damage inflicted to the protected public interest" (article 25, of the Decree and Article $9^{\circ}$ and 10, Law 18.381/08). 
The Access Unit to Public Information (UAIP) is an organism created to promote the access to information and the coordination between the public policies in the field (article 42). Within the scope of its operation, it can disqualify the information from "reserved" to "public", in the case where the justification presented is considered inadequate by the governmental authority which has issued the decision.

Although the legislative omission concerning the environment matter, it can be noticed that, in face of the concepts mentioned, "public information", a broad category which includes the environmental information, is defined as the pieces of information contained in public bodies. Access to this type of information is ensured for the public in order for the citizens' needs to be covered

\section{Paraguay}

The National Constitution of Paraguay (1992) determines that every person has the right to a healthy and ecologically balanced environment. It also sets the preservation, reconstitution and improvement of the environment as well as its conciliation with the full human development as a primary objective (article $\left.7^{\text {th }}\right)$.

The article 38, also part of the Constitution, states that every person can, individually or collectively, ask the public authorities for the implementation of measures to defend the environment. This right is classified as diffuse interest, once "there is a relation with the quality of life and with the public property".

As for the right to information access, the Paraguayan Constitution guarantees that every person has the right to generate, process and disseminate information, also protecting the freedom of expression and of the press as well as the right to propagation of thoughts and opinions. Consequently, those rights being constitutional, there is no law that could limit their freedom to be exercised (article 26).

Specifically referring to the right to information itself, article 28 recognizes that every person has the right to true, responsible, subjective and fair information.

Posterior to article 28, the General Education Law (Law 1.264/08) was approved in 2008, mandating (article 58) that the Paraguayan government encourages media participation in the permanent education processes and enhances the process of culture dissemination.

Also in 2008, the Secretariat of Information and Communication for Development (SICOM) was found through the presidential Decree 171. This institution was created to pursue the mission of linking the State and the community through communication and social dialogue, on the basis of a participative and transparent communication management mechanism (article $3^{\text {rd }}$.

Besides democratizing the information networks, the primary goal of the Governmental Communication policy is to extend the range and enhance the quality of education. 
Thus, like the case of Uruguay, there is not a specific Paraguayan legislation referring to environmental information. On the other hand, Paraguay has not even issued a law concerning the regulation of access to public information in general. However, even in the face of such an omission, the Paraguayan Constitution guarantees the basic, broad right of free access to information.

Such a guarantee covers the need for access to environmental information in the same way that general legislation regarding education covers the issue of Environmental Education, bearing in mind its essentiality for the development of the country.

\section{Argentina}

The Argentine Constitution includes national regulation regarding the responsibility of protection and preservation of a healthy, balanced environment, suitable for human development and not compromising future generations, imposing the obligation to preserve it on all legal subjects (article 41). It also entrenches the societal significance of the promotion of information and environmental education to the community.

The National Environmental Policy (Law 25.675/02) describes the minimum prerequisites for a sustainable and adequate to the environment economic management. The ultimate goal of this process is the preservation and protection of the biological diversity of the various ecosystems, as well as the realization of sustainable development (article $1^{\text {st }}$ ).

Article $8^{\circ}$, being included in this policy mixture, sets free access to environmental information as one of its basic instruments for the protection of the environment and sustainable development. It explicitly states that every individual or legal entity, public or private, should provide information referring to the environmental quality of its activities. Within the scope of this law "the authorities are responsible for informing about the state of the environment and the possible effects on it which can cause current and projected anthropogenic activities" (article 18).

Moreover, the legal text defines the social participation as mandatory, as it consolidates every citizen's right to be consulted regarding all sorts of administrative procedures related to the preservation and protection of the environment (article 19).

Regarding the legal retrenchment of the right to information access, the Law 25.831/04 has been updated. The new version of the law regulates free access to public environmental information, being valid nationwide and establishing the minimum level of protection of this right regarding access to information either owned by the State or self-regulatory entities and companies offering public services (article $1^{\text {st }}$ ).

According to this Law, "environmental information" is defined as any form of expression and manifestation related to the environment, the natural resources and the process of sustainable development (article $2^{\text {nd }}$ ). 
The law disposes, also, that the access to the information will be free of charge, and should be provided within 30 days from request, not being necessary to mention the fundamented reason to obtain it (article $3^{\text {rd }}$ and $8^{\text {th }}$ ).

As subjects being obliged to provide information concerning environmental matters are identified the following (article $4^{\text {th }}$ ): "the competent public authorities, and the public service providers, being either purely public, private or joint ventures".

Following article 4, law 25.831/04 was regulated by Decree 1172/03, guarantying the principle of publicity and ensuring the right to access public information. A prerequisite of participation has also been established for the purpose of controlling corruption, optimizing efficiency in the operation of governmental authorities and improving quality of life.

The Decree consolidates (Annex I) the general regulation of public hearings within the Executive Branch, claiming that this is a tool for ensuring participation in the decision-making processes as long as the responsible authority allows the interested parties to freely express their opinion.

It is also worth pointing out that the "Estados Provinciales", which compose Argentina, have the power to legislate environmental issues among other matters (article 121, Argentine Constitution).

Obviously, there are rules established by the provinces and also by Buenos Aires which not only fulfill the need for legal environmental protection but also consolidate the right to information access.

\section{Brazil}

In Brazil, in the end of the Military Dictatorship, the National Policy of Environment was enacted (Law 6.938/81), providing (articles $6^{\text {th }}$ and $10^{\text {th }}$ ) the framework of environmental research and licensing.

The Federal Constitution of 1988 , besides the guarantees of article $5^{\text {th }}$, subsection XIV and XXXIII, reinforces the wide societal dissemination of the information contained in the Environmental Impact Study for the cases of construction sites installation or performance of activities being likely to cause substantial environmental degradation (article 225, paragraph $1^{\text {st }}$, subsection IV).

Within this context, the operation and the activities undertaken by the National System for Environmental Information (SISNAMA) deserve to be highlighted. Established by the National Policy of Environment and regulated by the Decree $99.724 / 90$, the SISNAMA is an important tool for enhancing systemization, treatment, storing and dissemination of environmental information of various forms.

The tool responsible for the management of information contained in the SISNAMA is the National System for Environmental Information (SISNIMA).

The SISNIMA aims to integrate and share the information on the several existing national networks. It is regulated by the administrative rule of the Ministry of Environment (MMA) n ${ }^{\circ} 160$, which establishes the Information Policy of the Ministry of the Environment, operating in three main areas from 2009 onwards: development of access to information tools, integration of data 
bank and information network, and enhancement of the process of production, systemization and statistical analysis of the indicators related to the attributions of the MMA.

In 1997, the National Policy of Water Resources was enacted (Law 9.433/97), introducing the Information System about Water Resources as one of its main instruments (article $5^{\text {th }}$ ). This system should collect, treat, store and recover information about water resources in order to be able to guarantee public access to data and information (article 26).

There is, still, the Law 9.795/99, which establishes that the mass media have the responsibility of cooperating with National Policy of Environmental Education "in an active and permanent way serving the purpose of information dissemination and incorporation of the environmental dimension in educational practices" (article $\left.3^{\text {th }}\right)$.

This Policy also sets as a fundamental objective of environmental education the democratization of access not only to general information about the environment (article $5^{\text {th }}$ ) but also to studies, research projects and experiments aiming at "the dissemination of knowledge, technologies and information about environmental matters" (article $8^{\text {th }}$, paragraph 5).

Law 10.650/03 guarantees the accessibility of all the information available in the entities of SISNAMA, through "public access to documents, measures and administrative processes which address environmental issues" granted within 30 days from the request, by any citizen (article $2^{\text {nd }}$ ). In case of refusal, the decision has to be reasoned and is subjected to hierarchical appeal. In this way, any individual, regardless of providing proof of specific interest or not, has access to all available information, upon written request.

The same legislation establishes that some information on critical issues should be frequently updated regardless of any request (article $2^{\text {nd }}$ ). Among these issues are: environmental quality, policies, plans and programs having environmental impact as well as plans and actions regarding degraded areas recovery.

Law 12.305/2010, establishing the National Policy of Solid Residues, sets the right to information and social control (article $6^{\text {th }}$ ) as one among its basic principles. Social control is defined in the context of this law as "the full set of mechanisms and procedures which guarantee to society access to information and participation in the processes of design, implementation and assessment of public policies related to solid residues" (article $3^{\text {rd }}$ ).

Recently, Law 12.527/2011, being regulated by subsection XXXIII- article $5^{\text {th }}$ of Constitution, was edited to include, regulations regarding access to information concerning the environmental field.

This intradisciplinary legislation allows for a request to access information to be presented by any part interested, upon identification of the applicant and specification of the required information (article $1^{\text {st }}$ and 10). "Direct administration of the Executive, Legislative, and Judiciary Powers, the Public Prosecutor" as well as "autarchies, public foundations, public undertakings, mixed-economy companies and other entities controlled directly or indirectly 
by the Community, States, Federal District and Town" should be informed for free access to be granted.

Regarding this issue, there is a legal expression explicitly stating that "the access to information necessary to legal protection or administration of fundamental rights cannot be denied" (article 21). Legal procedures to protect this right can be exercised through Public Civil Action (Law 7.347/85).

Evidently, there are currently advanced laws consolidating the right to free and public access to environmental information. However,

the great challenge is in the instrumentalisation of the right to information through the establishment of procedures, terms, organization and standardization of databank, in order to be effectively used as a mechanism of popular participation in the governmental decisions and social control (GRAFF, 1998: 14).

\section{The Building of Sustainable Development through Environmental Awareness Resulting from Information}

The level of quality of information depends on its strategic nature and its ability to inspire motivation for the public's engagement into environmental issues. The quality and amount of information significantly influence the intensity with which the public participates in the sociopolitical sphere.

Whoever is uninformed will not be prevented from participating, but the quality of their participation will be harmed. Ignorance leads to either apathy or inertia of those who would be legitimized to participate (MACHADO, 2006: 34).

Citizens with access to high quality information are more likely to articulate desires and ideas in a decisive manner and thus, to take part in decisions directly concerning them, the defense of undisputable rights, such as the one to healthy and balanced environment included.

The right to information becomes, therefore, an essential prerequisite for active social participation in the public discourse.

The subject of right to information has a necessary interface with the right of the individual to be aware of the issues related to the protection of the environment as well as the subjective right to participate in political-administrative decisions of the State (SOARES, 2003: 611).

Civic engagement is considered the keystone of the struggle for an ecologically balanced environment. Access to sources of information and knowledge renders citizens capable of defending their own rights, conquering 
their citizenship and getting actively involved in the decision-making processes.

Environmental information being easily accessible is essential for the effective exercise of the right, also regarded as duty, to participate.

It is useless to establish ways of participating if the population doesn't have the necessary information to form their own opinion. This is why, as a projection and pre-requisite for participation, the Environmental Right has developed their own institutions related to the transparency of the public or private activities on the matter. I refer to the Right to Environmental Information (FERRER, 2013: $357)$.

The Rio Declaration on Environment and Development (created during ECO-92) asserts that the best way to deal with environmental issues is by ensuring civic participation through public access to information (Principle 10).

Environmental education depends on the quality and accessibility of relevant information, as civic participation requires access to information as well as training. Advanced environmental legislation is not enough if citizens are not educated enough to take initiatives for defense and protection of the environment.

Environmental education is needed to put an end to ignorance concerning the environment and its resources. Through the provision of high quality education basic actions and procedures related to the concept of the Environmental Right could be realised, such as the sustainable development, without which ensuring a high level of well-being would be impossible.

The Brundtland Report defines sustainable development as

A process of transformation in which the exploitation of resources, the aspects of investments, the orientation of technological development and the institutional change are harmonized and reinforce the present and future potential, in order to meet the human needs and aspirations (WORLD COMMISION ON ENVIRONMENT AND DEVELOPMENT, 1991: 9).

To meet the challenge of environmental sustainability efficient management of the existing natural resources is required, guarantying the fruitful interaction between men and nature through time.

The interplay between environment and the human factor should be grounded on the basis of public's awareness and education on environmental matters, primarily achieved through access to information. Thus, civic engagement and information access evidently contribute in the process sustainable development. "The progressive rise in public access to information, the participation and justice, produce more effective, fair and genuine decisions concerning policies and projects" (GONZALÉZ, 2007: 416). 
Citizens' access to environmental information constitutes a substantial pillar in the establishment of adequate participation systems as well as in the design and implementation of an effective environmental policy. Public awareness and civic participation render constitutional rules of environmental protection effective by impelling compliance with legislation. In this way, quality of life is expected to be enhanced and the environmental balance would be preserved for both the present and future generations. Therefore, information accessibility becomes the first step towards active civic participation in the decision-making process.

If there is adequate, reliable and truthful information, there is the possibility for society to form an objective opinion about environmental issues, and consequently, contribute to improve the environmental quality. In this context, collaboration is also considered necessary for sustainable development, as modern environmental rationality implies effective participation of the subjects potentially affected by authorities' decisions.

The principle of participation is a principle whose guidelines work with the clear advantage of tackling the environmental problems at source: the environmental awareness. What is expected from society is exactly a proud, altruistic, ethics and interactive position (RODRIGUES, 2002: 255).

For this reason, the National Policy of Environment (Law 6.938/81), stipulates that socio-economic development should be compatible with the preservation of the environmental quality and ecological balance. The policy mixture also indicates the three inseparable pillars composing sustainable development: the economic, the environmental and the social one (article $4^{\text {th }}$ ).

Environmental protection, economic growth and social equity should be in balance. Development cannot solely be environmentally sustainable, but also economically feasible and societally valuable, being an inseparable part of the social setting within which it was realised.

The principle of sustainable development reflects the concern with reaching development, using rational actions to preserve the essential processes and systems to life and the maintenance of ecological balance. It is necessary to think of building a more sustainable society, socially fair and ecologically balanced (BARRAL; FERREIRA, 2006: 28).

As discussed above, access to impartial information would raise social awareness about the environment, being a fundamental asset even in the legal context. Establishing a sustainable development system, being within the scope of Agenda 21, would only be possible on the basis of the public's awareness regarding the importance of the environment protection.

However, public policies addressing environmental education and awareness cannot be performed in a sectioned way. Therefore, integration on 
an international level among countries sharing the same borders and aspiring to form an economical, political and cultural union of the Latin American people, the MERCOSUR, is considered essential.

Integrated management is a fundamental element of a model of sustainability, aiming at the production and dissemination of high quality information translated into knowledge. Such a type of management would also enhance the provision of environmental education, benefiting the cooperation between Brazil, Uruguay, Paraguay and Argentina towards the defense and protection of the environment. It would also motivate civic participation, as the "cooperation among people for the progress of Humankind" is a principle which governs Brazil's strategy in its international relationships (article $4^{\text {th }}$, subsection IX, of the Brazilian Constitution).

However, the abovementioned progress intrinsically depends on the quality of the environment within which it is realised. The cooperation aims to promote, facilitate and guide the exchange of information, promoting the value of ecological balance and sustainable development.

The cooperation is, therefore, one of the basic normative instruments used to increase the amount of information available and expand civic involvement in decision-making processes concerning environmental policy.

Sustainability being a continuous process of global development rather than a static concept, planned and sustainable growth is considered necessary, ensuring the compatibility of social-economical development with the protection of environmental quality,

In these terms, the obligations of each country in the union are to ensure the continuous flow of information related to environment protection, as well as to create those mechanisms which would enhance social participation in environmental matters.

Consequently, information freely available for the citizens as well as cooperation between Latin American states are fundamental elements of the effective environmental policies' implementation, encouraging sustainable development, in the terms of Principle 12 of Rio Declaration on Environment and Development:

States should cooperate to promote a supportive and open international economic system that would lead to economic growth and sustainable development in all countries, to better address the problems of environmental degradation.

\section{Conclusion}

Public access to environmental information is considered to raise environmental awareness, providing the basis for a system based on sustainable development. Given the assertion that it is the community's obligation (as well as its power) to defend and protect the environment for the present and future 
generations (article 225, Brazilian Constitution), civic participation is a significant prerequisite for effective environment protection.

It is impossible for public discourse to be well-grounded and fruitful , lacking the provision of a broad information network. Public access to information allows citizens to participate effectively in the decision-making process as well as to supervise the level to which the political parties in power keep their promises in the implementation of public policy.

In this context, information becomes an indispensable tool in qualifying the public, so that the procedures of participative environmental democracy have satisfactory outcomes.

Thus, the principle of civic participation guarantees the protection of the environment on the legal level, as it allows public involvement in the specific actions in order to defend the collective right to a healthy environment as well as to contribute in the progress of sustainable development.

\section{References}

BARRAL, W. and FERREIRA, G. 2006. Direito Ambiental e Desenvolvimento. In BARRAL, W. and PIMENTEL, L. (eds). Direito Ambiental e Desenvolvimento. Florianópolis: Fundação Boiteux.

FERRER, G. 2013. La construción del Derecho Ambiental. In Revista Eletrônica Novos Estudos Jurídicos. Vol. 18, n. 3, pp. 347-368. Santa Catarina: UNIVALE. DOI $=$ www.univali.br/periodicos.

GRAFF, A. 1998. Direito a Informação Ambiental. In FREITAS, V. Direito Ambiental em Evolução. Volume 1. Curitiba: Juruá.

GONZALÉZ, L. 2007. Acceso a la justicia ambiental. In BENJAMIN, A., LECEY, E. and CAPPELLI, S. (eds.). $12^{\circ}$ Congresso Internacional de Direito Ambiental Meio ambiente e acesso à justiça: flora, reserva legal e APP. Volume 2. São Paulo: Imprensa Oficial do Estado de São Paulo.

MACHADO, P. 2006. Direito à informação e Meio Ambiente. São Paulo: Malheiros.

RODRIGUES, M. 2002. Instituições de Direito Ambiental. Volume 1. São Paulo: Max Limonad.

SOARES, G. 2003. Direito Internacional do Meio Ambiente: emergência, obrigações e responsabilidade. 2.ed. São Paulo: Atlas.

WORLD COMMISION ON ENVIRONMENT AND DEVELOPMENT. 1991. Nosso futuro comum. 2.ed. Rio de Janeiro: Editora Getúlio Vargas.

\section{Legislation Sites}

<http://200.40.229.134/leyes/AccesoTextoLey.asp?Ley=18381\&Anchor>.

<http://infoleg.mecon.gov.ar/infolegInternet/anexos/75000-79999/79980/norma.htm>.

<http://infoleg.gov.ar/infolegInternet/anexos/90000-94999/90763/norma.htm>.

<http://www.camara.gov.br/mercosul/Legislacao/TASSUNCAO.htm>.

$<$ http://www.cainfo.org.uy/images/Documentos/Legislacion/decreto_reglamentario_le yuy.pdf $>$.

<http://www.icaa.gov.ar/documentos/Ges_Ambiental/LEY_25831.pdf>.

$\langle$ http://www.mec.gov.py/talento/Normativas/ley_1264.pdf $>$.

$\langle$ http://www.mma.gov.br/port/sdi/ea/deds/pdfs/crt_belgrado.pdf $>$. 
